\title{
Abnormal Hard Tissue Formation in Pulp
}

National Cancer Institute

\section{Source}

National Cancer Institute. Abnormal Hard Tissue Formation in Pulp. NCI Thesaurus. Code C34334.

Development of hard tissue in the inner substance of the tooth where blood vessels, lymphatic, and nerve tissue is normally found. 